\title{
Increasing maize productivity by presowing usage of biologies Mycofriend, Mikovital and Florobacillin
}

\author{
Serhii Dymytrov ${ }^{1, *}$, Vasil Sabluk ${ }^{2}$, Semen Tanchyk ${ }^{1}$, Mykhailo Gumentyk ${ }^{2}$, and Oleg \\ Balagura $^{2}$ \\ ${ }^{1}$ National University of Life and Environmental Sciences, 15 Heroes of Defense, 03041, Kyiv, \\ Ukraine \\ ${ }^{2}$ Institute of Energy Crops and Sugar Beet, 25 Clinichna, 03110, Kyiv, Ukraine
}

\begin{abstract}
The aim is to study how presowing usage of biologies Mycofriend, Mikovital and Florobacillin influences on biometric indicators of maize, its productivity and soil moisture holding capacity. Using mycorrhizal fungi and nitrogen-fixing bacteria, we have received positive results about their influence on plant growth and development and maize yield forming. Leaf surface area in variants with fungi Trichoderma harzianum RIFAI (Mycofriend bio-based product), and Tuber melanosporum VITTAD (Mikovital bio-based product) and bacteria Bacillus subtilis Cohn. (Florobacillin bio-based product) was counted on 30th, 60th, 90th and 120th days of vegetation and was estimated by $11.2-90.0 \%$ higher compared to the control. Leaf mass and root system mass exceeded control indicators by $24.0-48.9 \%$, respectively. Plants height in these accounted periods was higher by $4.0-31.5 \%$ compared to the control. In addition, in these variants, soil moisture holding capacity increased by $7.3-38.1 \%$, share of soil lumps smaller than $0.25 \mathrm{~mm}$ decreased by $2.8-7.2 \%$. Grain yield of Maize in variants with mycorrhizal fungi and nitrogen-fixing bacteria was 1.64-2.68 t/ha higher than in the control. It should be noted that presowing usage of fungus Trichoderma harzianum RIFAI on plants seeds, provides better efficiency on plants' growth and development and their productivity.
\end{abstract}

\section{Introduction}

Biological and agricultural researches dedicated to improving stability of agricultural production and reducing its losses have become important over recent years $[1,2]$. The problem of providing plants with moisture has become of even greater importance.

Water content decrease causes a number of biochemical processes in a plant, which negatively affects photosynthesis process [3].

The plant begins to expend moisture from the moment of seeds germination. However, moisture losses at this stage are insignificant. Maize begins to absorb a lot of moisture after emergence, and almost all moisture is used for evaporation (transpiration) [4].

\footnotetext{
Corresponding author: sdimitrov@ukr.net
} 
Lack of moisture slows down chlorophyll biosynthesis. In drought, chlorophyll is often destroyed. Leaves yellowing during severe droughts is a common external mark of water deficit [5].

Drought stress and insufficient soil aeration induce water content decrease in plant tissues, which leads to slowing down or stopping their growth, browning, drying and leaf fall. At the same time, there is a mass dying-off of small roots and growth inhibition both during and after the drought [6].

Soil moisture has a significant effect on roots activity for water absorption. However, its significant part in the soil is unavailable for plants. Difference between available and unavailable moisture of soil with different mechanical composition defines its moisture supply.

Fungi of arbuscular mycorrhiza (AM), which have a multifunctional effect on plants, facilitate growth of root system's absorptive capacity, which increases intensity of nutrient absorption and reduces negative effects of drought and soil salinity [7].

This is because water is an indispensable resource and condition for plants' existence. Water environment is necessary for all types of biochemical reactions that take place in plants [8].

Mycorrhiza can affect integrity of membranes, which is proved by higher concentration of electrolytes in plants roots inoculated with arbuscular mycorrhiza (AM) fungi and lower level of their yield [9].

For efficient growth and development of maize plants we have used symbiotic microorganisms with different dominant function: mycorrhizal, nitrogen fixation, phosphate mobilization, protection against phytopathogens, etc., which improves nutrition and reduces pesticide load on agrocenosis [10].

Obtained results confirm many researchers' conclusions, that using mycorrhizal fungi and nitrogen-fixing bacteria contributes to better moisture supply of plants, and hence nutrients. In particular, V. V. Volkohon, O. V. Nadkernychna, T. M. Kavalevska et al. [11] claim that this will allow plants to improve moisture supply.

\section{Materials and research methods}

Research was conducted at the Institute of Bioenergy Crops and Sugar Beets of National Academy of Sciences of Ukraine on the basis of Veselopodilsk Research and Breeding Station (VPDSS), which is located on the Left-Bank Forest-Steppe of Ukraine. Soil cover is marked by diversity of colours. Alkaline and weakly-alkalinized chernozems predominate.

Researches were conducted in the field crop rotation repeated 4 times, size of accounting area was $25 \mathrm{~m}^{2}$. For our research we have used fungi of vesicular-arbuscular mycorrhization Tuber melanosporum VITTAD (Mikovital bio-based product) and Trichoderma harzianum RIFAI (Mycofriend bio-based product) and bacteria Bacillus subtilis Cohn. (Florobacillin bio-based product).

According to research program we have defined water content and mass of leaves and root system, leaf surface area for 30th, 60th, 90th and 120th days of vegetation, soil moisture holding capacity and its physical state and yield.

In particular, to define root system mass of maize plants, we have selected 10 plants on protective strip in each repetition in the same period. Root system was dug out at $30 \mathrm{~cm}$ depth and cut to root collar, cleaned from the ground, washed with water, dried for 1 hour, weighed on laboratory scales.

To establish leaf water content of maize plants by determining their mass, collection was carried out after 30th, 60th, 90th and 120th days of vegetation. 100 leaves in each variant (25 leaves from each repetition) were selected and weighed on laboratory scales no 
later than an hour. Obtained data were processed using statistical calculation methods [12, $13,14]$.

Leaf surface area of zea maize was also determined on the 30th, 60th, 90th, 120th days of plant vegetation according to A. A. Nichiporovich method [15], as well as using "Petiole" software $[16,17,18]$.

Plants height was also determined at the same period. To do this, 10 plants were selected in each repetition and measured with a ruler.

\section{Research results}

Obtained data for 2017-2019 years show that mycorrhizal fungi and nitrogen-fixing bacteria in symbiosis with root system of maize plants provide increase of all indicators that were studied compared to the control. In particular, in these variants there is a significant increase of maize leaf water content during all four calculations compared to the control (Table 1).

Thus, mass of 100 leaves of zea mays after 30 days of vegetation in variants with fungi Trichoderma harzianum RIFAI. (Mycofriend bio-based product), Tuber melanosporum VITTAD. (Mikovital bio-based product) and bacteria Bacillus subtilis Cohn. (Florobacillin bio-based product) was 32-38 g higher than the control. In later vegetation periods, these indicators were higher than the control by $24.0-48.9 \%$ (Fig. 1).

A similar trend is observed concerning mass of maize plants root system. According to the data in Figures 1 and 2, this indicator exceeds the control by 13.6-112.0\% in all periods of accounting.

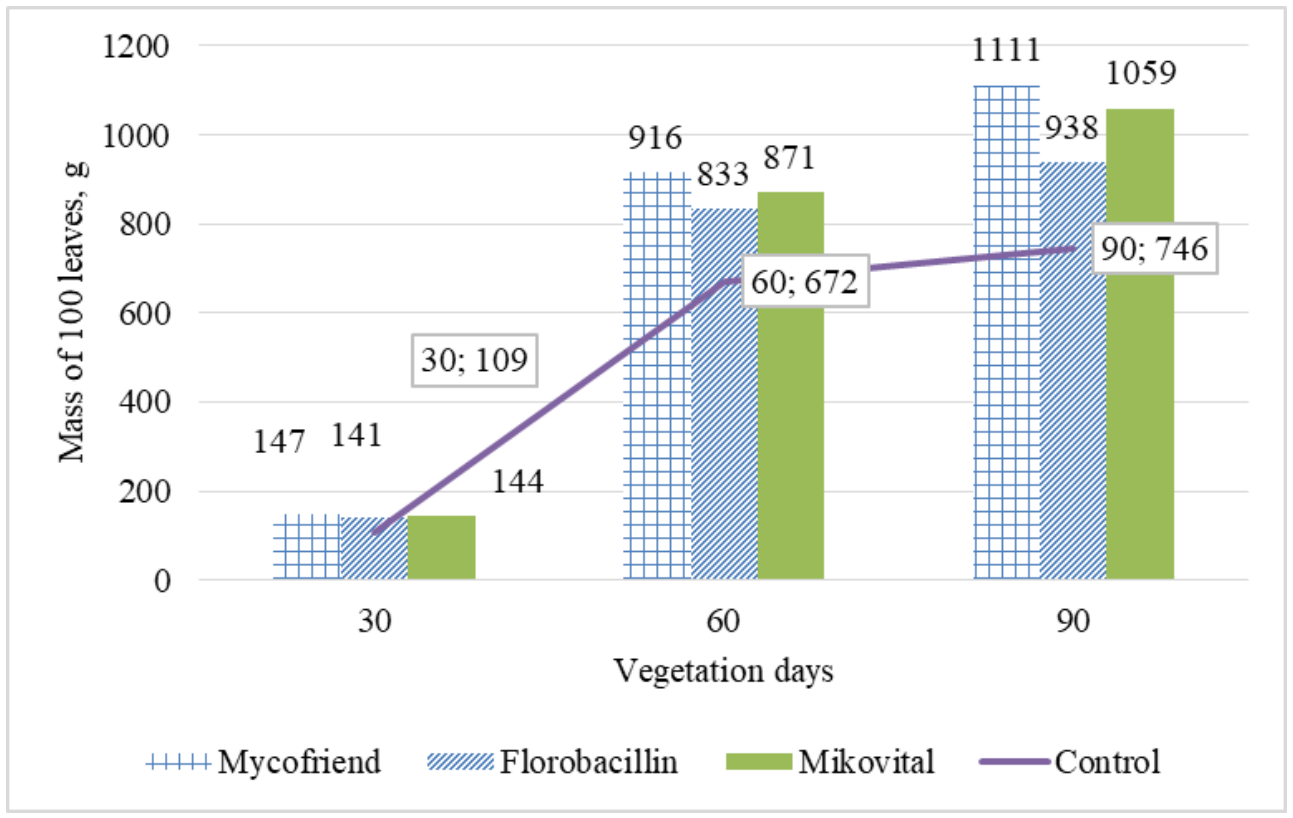

Fig. 1. Maize plants leaf mass depending on usage of mycorrhizal fungi and nitrogen-fixing bacteria, VPDSS, 2017-2019 years.

Increase in leaf mass and root mass is happening due to symbiosis of microorganisms with root system, formation of a new cluster of roots fibrilla from fungi hyphae, which facilitate better nutrients absorption, namely phosphorus and water. 


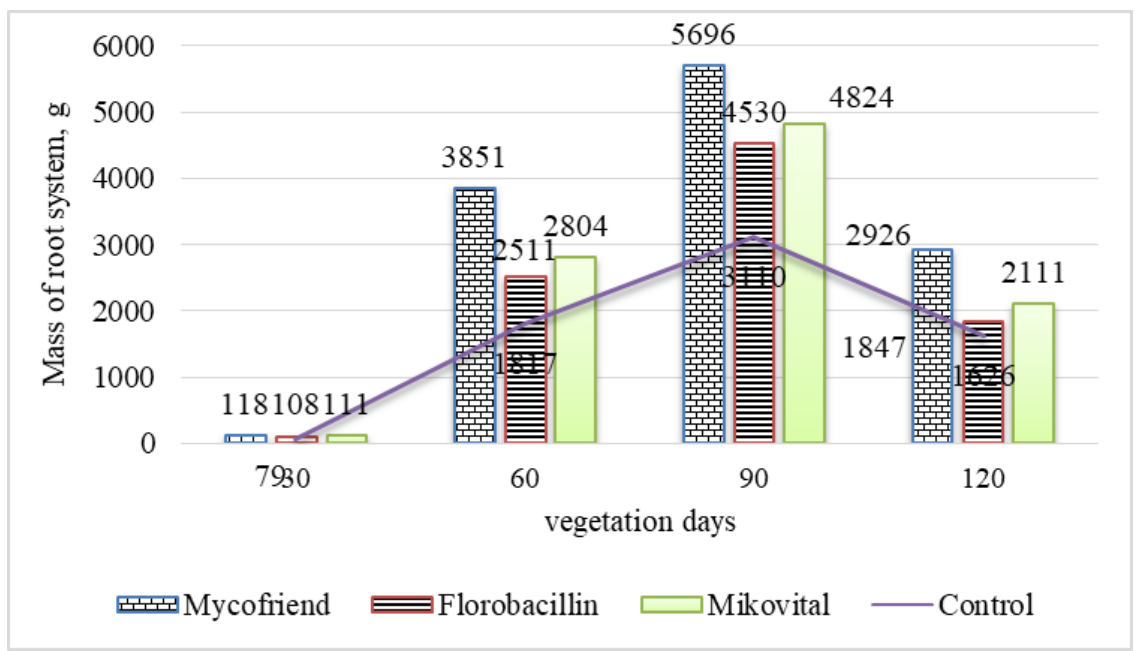

Fig. 2. Mass of maize plants root system depending on usage of mycorrhizal fungi and nitrogenfixing bacteria, VPDSS, 2017-2019 years.

Leaf surface area of zea maize plants exceeds control indicators in the variants with Mycofriend, Mikovital and Florobacillin biologies. In the areas, where Mycofriend biobased product was used, plants leaf surface area was $4.16-68.1$ thousand $\mathrm{m}^{2} /$ ha, with Mikovital - 3.79-63.3, and with Florobacillin bio-based product - 3.79-63.3 thousand $\mathrm{m}^{2} /$ ha, or it was higher than control by $11.2-90.0 \%$ (Table 1 ).

Table 1. Leaf surface area of zea maize plants using mycorrhizal fungi and nitrogen-fixing bacteria, VPDSS, 2017-2019 years.

\begin{tabular}{|c|c|c|c|c|c|c|c|c|c|c|c|c|c|}
\hline \multirow{4}{*}{ 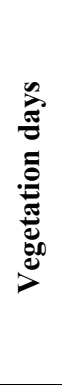 } & \multicolumn{13}{|c|}{ Leaf surface area } \\
\hline & \multirow{3}{*}{ 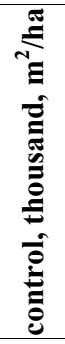 } & \multicolumn{4}{|c|}{ Mycofriend } & \multicolumn{4}{|c|}{ Florobacillin } & \multicolumn{4}{|c|}{ Mikovital } \\
\hline & & \multirow{2}{*}{ 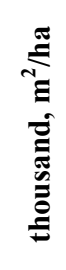 } & \multicolumn{3}{|c|}{ +- before control } & \multirow{2}{*}{ 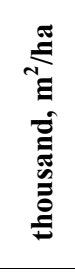 } & \multicolumn{3}{|c|}{ +- before control } & \multirow{2}{*}{ 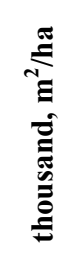 } & \multicolumn{3}{|c|}{ +- before control } \\
\hline & & & 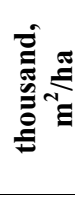 & $\%$ & 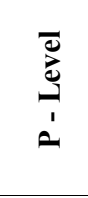 & & 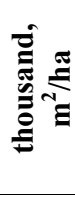 & $\%$ & 离 & & 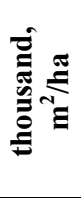 & $\%$ & 苞 \\
\hline 30 & 2,19 & 4,1 & 1,97 & , & 0,0 & $J$, & 1,22 & Ju & , & 3,79 & 1,00 & 13 & J, \\
\hline 60 & 38,6 & 49,5 & 10,9 & 28 & 0,01 & 43, & 4,34 & 1 & 0,01 & 4. & 6,49 & 16 & 0,01 \\
\hline 90 & 55,1 & 68,1 & 13,0 & 23,5 & 0,009 & 62,9 & 7,83 & 14,2 & 0,009 & 63,3 & 8,24 & 15,0 & 0,01 \\
\hline 120 & - & - & - & - & & - & - & - & & - & - & - & \\
\hline
\end{tabular}

Note: On the $120^{\text {th }}$ day of vegetation, the plants were in the dying-off phase.

Similarly, in variants with Mycofriend, Mikovital and Florobacillin biologies, plant height indicators prevail in comparison with control. In particular, when using bio-based product Mycofriend plant height was in the range from 48 to $220 \mathrm{~cm}$, bio-based product Mikovital - 47-204 cm and bio-based product Florobacillin - 46-200 cm. Exceedance of control indicators in these variants was $4.0-28.8 \%$ (Table 2). 
Table 2. Maize plants height using mycorrhizal fungi and nitrogen-fixing bacteria, VPDSS, 20172019 years.

\begin{tabular}{|c|c|c|c|c|c|c|c|c|c|c|c|c|c|}
\hline \multirow{4}{*}{ 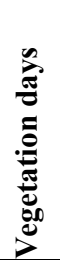 } & \multicolumn{13}{|c|}{ Plants height } \\
\hline & \multirow{3}{*}{ 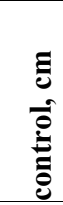 } & \multicolumn{4}{|c|}{ Mycofriend } & \multicolumn{4}{|c|}{ Florobacillin } & \multicolumn{4}{|c|}{ Mikovital } \\
\hline & & \multirow[b]{2}{*}{$\mathbf{c m}$} & \multicolumn{3}{|c|}{ +- before control } & \multirow[b]{2}{*}{$\mathbf{c m}$} & \multicolumn{3}{|c|}{ +- before control } & \multirow[b]{2}{*}{$\mathbf{c m}$} & \multicolumn{3}{|c|}{ +- before control } \\
\hline & & & $\mathbf{c m}$ & $\%$ & $\begin{array}{c}\text { P - } \\
\text { Level }\end{array}$ & & $\mathbf{c m}$ & $\%$ & $\begin{array}{c}\text { P - } \\
\text { Level }\end{array}$ & & $\mathbf{c m}$ & $\%$ & $\begin{array}{c}P \text { - } \\
\text { Level }\end{array}$ \\
\hline 30 & 37 & 48 & 12 & 31,5 & 0,03 & 46 & 9 & 24,7 & 0,03 & 47 & 11 & 28,8 & 0,02 \\
\hline 60 & 211 & 244 & 33 & 15,4 & 0,009 & 223 & 12 & 5,5 & 0,02 & 230 & 19 & 9,2 & 0,008 \\
\hline 90 & 235 & 257 & 2 & 9 & 0 & 245 & 1 & 4 , & 0,0 & 247 & 12 & 5 , & 0,02 \\
\hline 120 & 187 & 220 & 33 & 17,6 & 0,009 & 200 & 13 & 6,7 & 0,01 & 204 & 17 & 9,3 & 0,009 \\
\hline
\end{tabular}

Apart from researching impact of mycorrhizal fungi and nitrogen-fixing bacteria usage on the growth and development of maize plants, we have also determined soil moisture holding capacity and physical state of maize crops. It was found that in the variants with these organisms, moisture holding capacity of soil was $7.3-38.1 \%$ higher than in the control, and proportion of lumps smaller than $1 \mathrm{~mm}$ was $2.8-7.2 \%$ lower (Figs. 3, 4).

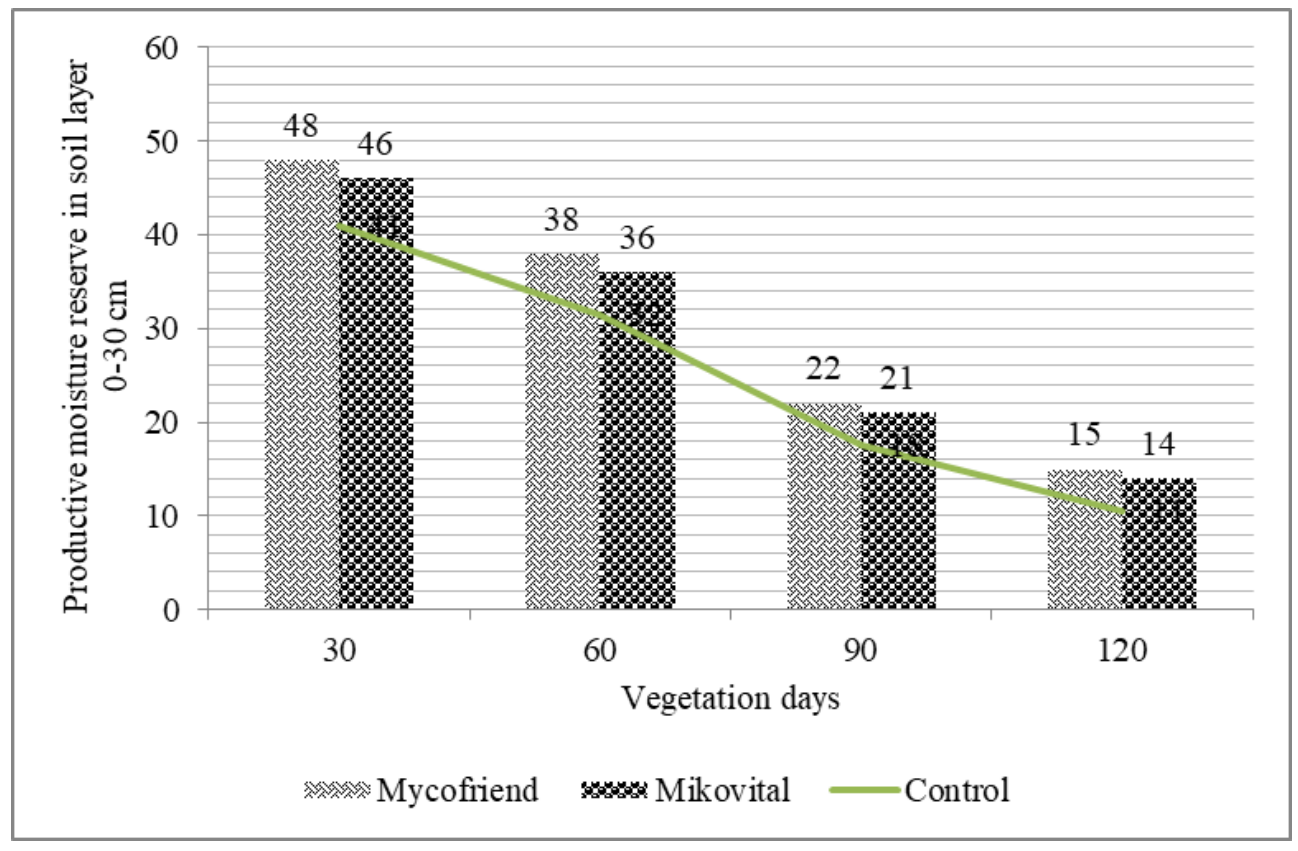

Fig. 3 Moisture holding capacity of soil during symbiosis of mycorrhizal fungi with maize plants root system, VPDSS, 2017-2019 years. 


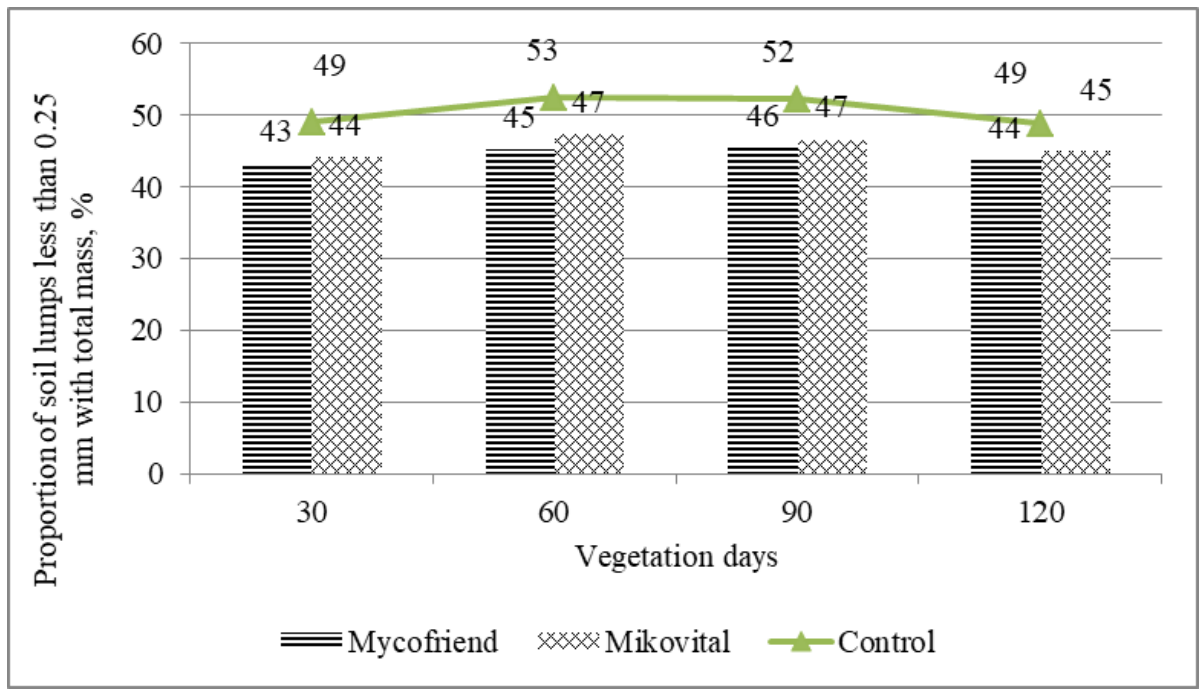

Fig. 4 Physical state of soil during symbiosis of mycorrhizal fungi with maize root system, VPDSS, 2017-2019 years.

These indicators prove that symbiosis between fungi and plants root system changes soil physical state and its moisture holding capacity. It is known from literature references $[19,20]$ that these changes, first of all, occur by means of creating mycelial network and forming adhesive component of glucoprotein-glomatin.

Enhancement of nutrients for plant growth and development and soil quality using mycorrhizal fungi and nitrogen-fixing bacteria improved maize grain yield, which in these variants was $1.65-2.68 \mathrm{t} /$ ha higher than the control (Table 3 ).

Table 3. Maize yield using mycorrhizal fungi and nitrogen-fixing bacteria, VPDSS, 2017-2019 years.

\begin{tabular}{|c|c|c|c|c|c|c|c|c|c|c|}
\hline \multirow[b]{3}{*}{ Years } & \multicolumn{10}{|c|}{ Yield, t/ha } \\
\hline & \multirow[b]{2}{*}{ 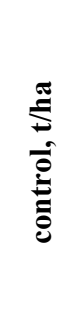 } & \multicolumn{3}{|c|}{ Mycofriend } & \multicolumn{3}{|c|}{ Florobacillin } & \multicolumn{3}{|c|}{ Mikovital } \\
\hline & & t/ha & 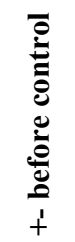 & 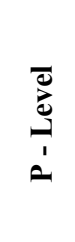 & t/ha & 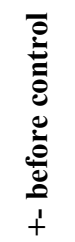 & 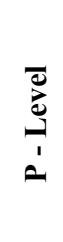 & t/ha & 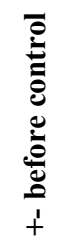 & 'ئ. \\
\hline 2017 & 7,80 & 10,18 & 2,38 & 0,03 & 9,69 & 1,89 & 0,03 & 9,96 & 2,16 & 0,03 \\
\hline 2018 & 9,18 & 11,98 & 2,80 & 0,02 & 11,40 & 2,22 & 0,02 & 11,71 & 2,53 & 0,02 \\
\hline 2019 & 5,65 & 8,50 & 2,85 & 0,04 & 6,47 & 0,82 & 0,04 & 7,19 & 1,54 & 0,04 \\
\hline average & 7,54 & 10,22 & 2,68 & & 9,19 & 1,65 & & 9,62 & 2,08 & \\
\hline
\end{tabular}

Results of our research coincide with conclusions of Z. Guralchuk [21] that increasing rhizosphere soil volume occurs due to symbiosis of living organisms with plants root system, which further significantly affects their leaf surface area and height, moisture holding capacity and soil physical state. 


\section{Conclusions}

Presowing usage of biologies Mycofriend, Mikovital and Florobacillin on maize seeds contributes to enhancement of such bioenergy indicates of growth and development as root and leaves mass, plant's height and leaf surface area by 4,0-112,0\% compared to control.

Due to symbiosis between mycorrhizal fungi and nitrogen-fixing bacteria with maize plants' root system, moisture holding capacity of soil and its physical state has increased by 2,8-38,1\%. Maize grain yield in variants with Mycofriend, Mikovital and Florobacillin biologies was higher by $1,65-2,68 \mathrm{t} / \mathrm{ha}$ compared to control.

\section{References}

1. Romanenko, S.M. (2015). Current issues of ensuring the environmental safety of agricultural products and the implementation of legislation on organic production. In Orhanichne vyrobnytstvo i prodovolcha bezpeka, Zhytomyr: Polissia, 186-194.

2. Mamenko, T.P., Yaroshenko, O.A., \& Yakimchuk, R.A. (2009). Water status and yield of winter wheat under the drought and salicylic acid actions. Physiology and Biochemistry of Cultivated Plants, 41(5), 447-453.

3. Rozumova, S.H. (2013). Ekolohiia roslyn z osnovamy botaniky ta fiziolohii. Odesa: Odesa State Environmental University.

4. Kaminskyi, V.F., \& Gangur, V.V. (2018). Dynamics of productive moisture in the soil for the cultivation of winter wheat in the crop rotations of the Left-Bank Forest-Steppe of Ukraine. Bulletin of Poltava State Agrarian Academy, (3), 11-14. https://doi.org/10.31210/visnyk2018.03.01

5. Prysiazhniuk, O.I., \& Korovko, I.I. (2015). Dynamic pattern of chlorophyll content in the leaves of sugar beet. Advanced Agritechnologies, 1(3). https://doi.org/10.21498/na.1(3).2015.118908

6. Kolesnichenko, O.V. (2015). Anatomical and morphological structure of leaves Castanea sativa Mill. as a factor in the stabilization of the water regime of plants under drought conditions. Scientific reports NULES of Ukraine, (5). http://nd.nubip.edu.ua/2015 5/31.pdf

7. Smith, S.E., \& Read, D. (Eds.). (2008). Mycorrhizal symbiosis (3nd Ed.). London: Academic Press. https://doi.org/10.1016/B978-0-12-370526-6.X5001-6

8. Kovalevskii, S.B., \& Kryvokhatko, H.A. (2018). Drought resistance and water retention capacity of plants of Th. occidentalis L. and its cultivars. Scientific Bulletin of UNFU, 28(2), 77-80. https://doi.org/10.15421/40280214

9. Kaya, C., Ashraf, M., Sonmez, O., Aydemir, S., Tuna, A.L., \& Cullu, M.A. (2009). The influence of arbuscular mycorrhizal colonisation on key growth parameters and fruit yield of pepper plants grown at high salinity. Scientia Horticulturae, 121(1), 1-6. https://doi.org/10.1016/j.scienta.2009.01.001

10. Moldovan, Z.A., \& Sobchuk, S.I. (2018). An estimation of indexes of the individual productivity of plants of corn is at presowing treatment of seed and outside the roots signup. Grain Crops, 2(1), 101-108. https://doi.org/10.31867/2523-4544/0014

11. Volkohon, V.V., Nadkernychna, O.V., Kovalevska, T.M., Tokmakova, L.M., Kopylov, Y.P., Kozar, S.F., Tolkachev, M.Z., Melnychuk, T.M., Chaikovska, L.O., Sherstoboiev, M.K., Moskalenko, A.M., \& Khalep, Y.M. (2006). Mikrobni preparaty u zemlerobstvi. Teoriia i praktyka. V.V. Volkohon (Ed.). Kyiv: Ahrarna nauka.

12. Rozhkov, A.O., Puzik, V.K., Kalenska, S.M., Puzik, L.M., Popov, S.I., Muzafarov, N.M., Bukhalo, V.Y., \& Kryshtop, Y.A. (2016). Doslidna sprava v ahronomii. Knyha 1. Teoretychni aspekty doslidnoi spravy. A.O. Rozhkov (Ed.). Kharkiv: Maidan. 
13. Tsarenko, O.M., Zlobin, Y.A., Sklyar, V.H., \& Panchenko, S.M. (2010). Kompiuterni metody v silskomu hospodarstvi ta biolohii. Sumy: Universytetska knyha.

14. Didora, V.H., Smahlii, O.F., \& Ermantraut, E.R. (2013). Metodyka naukovykh doslidzhen $\mathrm{v}$ ahronomii. Kyiv: Tsentr uchbovoi literatury.

15. Nichiporovich, A.A., \& Kuperman, F.M. (1966). Photosynthesis and issues of increasing plant productivity. Bulletin of Agricultural Science, (2), 1-12.

16. Petiole LTD. (2019). Petiole - Petiole Leaf Area Meter (Version 2.0.1). https://play.google.com/store/apps/details?id=com.petioleapp.petiole

17. Polunina, O.V., Maiboroda, V.P., \& Seleznov, A.Y. (2018). Evaluation methods of estimation of young apple trees leaf area. Bulletin of Uman National University of Horticulture, (2), 80-82. https://doi.org/10.31395/2310-0478-2018-21-80-82

18. Hrytsak, L.R., Herts, A.I., Nuzhyna, N.V., Cryk, M.M., Shevchenko, V.V., \& Drobyk, N.M. (2018). The influence of light regime on the growth data and pigment composition of the plant Gentiana lutea cultured in vitro. Regulatory Mechanisms in Biosystems, 9(2), 258-266. https://doi.org/10.15421/021838

19. Kough, J.L., Molina, R., \& Linderman, R.G. (1985). Mycorrhizal responsiveness of Thuja, Calocedrus, Sequoia, and Sequoiadendron species of western North America. Canadian Journal of Forest Research, 15(6), 1049-1054. https://doi.org/10.1139/x85170

20. Newman, E.I., \& Reddell, P. (1987). The distribution of mycorrhizas among families of vascular plants. New Phytologist, 106(4), 745-751. https://doi.org/10.1111/j.1469$\underline{\text { 8137.1987.tb00175.x }}$

21. Guralchuk, Z. (2011). Effect of arbuscular mycorrhiza on the uptake of nutrients and plant tolerance to unfavorable environmental factors. Agriciltural Microbiology, (12), 7 26. 